\title{
Academics, cricket and apartheid
}

The British seem to be heading for trouble in their sporting relations with South Africa, but the case for an academic boycott remains as insubstantial as it has always been.

DURING their creative period, mostly in the nineteenth century, the British were renowned for the invention of athletic pursuits, not merely individual activities such as mountain climbing (Edward Whymper), but team games, among which cricket and rugby football are the best known. (Association football, otherwise known as soccer, which came later, is more easily understood - which probably explains why it is less distinctively a part of the snobbish British ethos.) In the course of a prosperous century, British colonial administrators, nostalgic for their childhood playing fields, took care to teach the intricate rules of their national games to those in their charge, but with the predictable result: the colonials (now all excolonials), being generally more athletic and, in any case, eager to make an anti-colonial argument, quickly learned how to beat the British at their own games.

That truth has been demonstrated with telling clarity this summer, when a group of Australian visitors to Britain has beaten into humiliation an English cricket team. (Cricket is not so much a British as an English sport.) For the promoters and the supporters of the game, there now remains the embarrassment of knowing what to make of the two remaining pre-arranged contests (laughingly called matches) at which the only glimmer of interest will be whether the beaten team can rise like a phoenix from the ashes of defeat. (The prospects would have been even worse if the visitors had been West Indian.) The gloom over English cricket has now been further deepened by the decision of 16 professional cricketers to spend the next two austral summers playing cricket in South Africa, the ex-colonial nation, now a free-standing republic, whose chief claim on public attention is the doctrine of apartheid. One consequence will be that those who go to South Africa will be excluded from the English cricket team for at least five years - prospective 'rebels' have already been dropped - so further undermining the English cricket team. Another is that there will be further endless trouble about English or, more generally, British representation in international sport. Matters are likely to be worsened if rumours that British rugby footballers are about to set off for South Africa should be confirmed.

On the face of things, this impending fuss, based on a formal agreement between sporting authorities within the British Commonwealth that there should be a boycott of sporting fixtures with South Africa, contrasts awkwardly with the opinion of journals such as this that a boycott of cultural and academic institutions in South Africa would be intolerable (see Nature 327, 259; 1987). Why, it may be asked, should there be one (and a harsh) rule for those who play cricket and quite a different rule for academics? The answer, luckily, is simpler than it seems, but is necessarily dependent on knowing what is happening in South Africa.

First, the case for a boycott of South Africa in sports is strong and unchanged by the events of the past decade. South Africans play both cricket and rugby football excellently, and are forever seeking ways in which to demonstrate their skill. But those who play these games are predominantly white, and those who regulate the two sports are almost exclusively so. It is no longer against the apartheid rules for people of different ethnic origins to be members of the same teams, but changes in these directions have so far been largely tokens. Given the physical segregation of ethnic populations, cricket or rugby football teams formed naturally are likely to be of uniform ethnic composition. In any case, the people of the black and coloured townships have other things on their minds than cricket and rugby football. It might be different if they believed that excellence would allow them, in their turn, to beat white South Africa at its own games.

In the circumstances, the only surprise is that the international cricket authorities seem content with a fiveyear ban on those who play in South Africa. Why not a lifelong ban? The case of the South African universities is different. At least two of them (Witswatersrand and Cape Town) are citadels of enlightenment in an otherwise blinkered land. At great risk to their own immediate interests, they are a principal source of higher education for black and coloured populations in South Africa. But even Afrikaans universities such as Stellenbosch have recently surprised even themselves by the liberality of their opinions on social matters even if they have not yet squarely faced the need that the attaintments required of entering students should be adjusted to suit their preparation at school.

Moreover, there is every reason to expect that the same institutions will have a crucial part to play in the postapartheid society that cannot be much longer delayed in South Africa. That is why there must be one rule for academics and another for sportsmen. 